\title{
DIABETOGENIC PROPERTY OF CHARRED MEAT ON LITTERS OF PREGNANT ALBINO RATS
}

\author{
A. D. ESSIEN and J. O. AKPAN \\ Department of Pharmacology, Faculty of Basic Medical Sciences, College of Medical \\ Sciences, University of Calabar, Calabar, Cross River State, Nigeria. \\ Tel: +2348023574556, +2348037930135
}

\begin{abstract}
Summary: Intake of nitrosamine - rich food has been implicated in the pathogenesis of childhood type 1 diabetes mellitus. The present study therefore examines a possible relationship between consumption of charred meat, rich in nitrosamine during pregnancy and the corresponding development of type 1 diabetes in their litters. Determination of blood glucose and serum insulin levels in litters showed percent charred meat related increase in the mean blood glucose values of $64.1 \pm 1.39 \mathrm{mg} / \mathrm{dl}$ compared with the mean control value of $53.8 \pm 3.78 \mathrm{mg} / \mathrm{dl}$ and a corresponding reduction in the mean serum insulin values of $2.0 \pm 0.43 \mu \mathrm{U} / \mathrm{ml}$ compared with $5.8 \pm 0.29 \mu \mathrm{U} / \mathrm{ml}$ in the control $(\mathrm{P}<0.05)$. There were no significant changes in the mean blood glucose level and serum insulin level among the corresponding pregnant rats, hence, no evidence of diabetes mellitus. These results suggest that meat, when subjected to charcoal fire roasting may be harzardous to the foetus and a causative factor in the development of type 1 diabetes mellitus in the litters.
\end{abstract}

Key Words: Charred meat, type 1 diabetes mellitus, serum insulin, blood glucose.

\section{Introduction}

Type 1 Diabetes Mellitus (Insulin Dependent Diabetes Mellitus, IDDM) has been on the increase for several years and in children between zero to four years of age (Ruwaard $e t$ al, 1994) and in Port Harcourt (Nigeria) 18.9 percent of the population are diabetic without a confirmed causative factor (Nwafor and Owhoji, 2001). In 1998, WHO described type 1 diabetes as a major health problem.

Several chemicals such as nitrates and nitrites used as food additives and in meat curing are ubiquitous in plants, are found naturally in many foods, and are implicated in health problems such as liver and kidney cancers, when subjected to dry heating (Felton and Knize, 1990). The formation of carcinogens is complex and depends highly on the practical details of cooking (Felton and Knize, 1990). Van Maanen, et al (1996) described a controversial relationship between nitrate exposure and childhood IDDM on evaluating the health risk of nitrate in drinking water. A nitrosamine - rich diet of curred mutton has been shown to cause damages to pancreatic beta cells and hence may possibly induce diabetes mellitus (Helgason et at 1982).

In childhood diabetic study in Sweeden, Dahlquist et al (1991) observed a dose response relationship between intake of nitrosamine rich food (vegetables) and type 1 diabetes, though in a similar study in Australia, Verge (1994) observed no relationship between type 1 diabetes and an intake of nitrosamine - rich food.

Meat contains compounds like Dimethylnitrosamine (DMN) and Diethylnitrosamine (DEN) which are naturally at low concentration (Rywotycki, 2000). But when subjected to high temperature, the concentration is raised to a level that is carcinogenic (Rywotycki, 2000) to kidney and liver and perhaps other organs. (Takayuki and Bjeldanes, 1993). It is likely that, when meat is charred (charcoal fire roasting) and consumed frequently and in large quantities, the nitrosamine exposure will be high and hazardous to the exposed individual especially, the foetus. Roasted meat, popularly known as "soya meat" in Nigeria is observed to be frequently consumed in our society, for 
example, in Calabar Municipality, Nigeria, especially by pregnant women, some of whom crave for such meat from the roadside.

The high incidence of type 1 diabetes, the variation in report of nitrosamine - rich food induced IDDM and high consumption rate of roasted meat by pregnant women led us to examine further the role of charred meat intake and the possible development of type 1 diabetes in their offsprings.

\section{Materials and Methods}

Animals: Forty mice were obtained from the animal house of the Department of Pharmacology, College of Medical Sciences, University of Calabar. Twenty female albino rats were also obtained from the animal house of the Department of Pharmacology, College of Medical Sciences, University of Calabar.

The animals were caged in plastic cages with stainless steel mesh floor and well ventilated tops. The cages were equipped with stainless steel feed containers and plastic drinkers with stainless nozzles. Saw dust was used as beddings and were changed daily. The animals were housed under a conducive and well ventilated environment, room temperature of 29 $\pm 1^{0} \mathrm{C}$ and 12 hours day light/darkness cycle. The feed (from commercial stock of Agro Feed Nigeria Plc) and tap water were available $a d$ libitum.

Determination of Toxic Dose (TD): This was carried out using thirty-five (35) randomly selected mice and were divided into seven groups (mean weight of $20.1 \pm 0.3 \mathrm{gm}$ ) that were fed on charred meat: normal feed ratio of $0: 10,1: 9,2: 8,4: 6,6: 4,8: 2,10: 0$ respectively, corresponding to $0,10,20,40,60,80$ and 100 percental feeding regimen for a period of three days. The responses - mean weight changes (weight reduction) were determined and plotted as dose-response curve. With the corresponding "probit scale" curve, three doses were extrapolated to be 40,60 and 80 percent corresponding to $\mathrm{TD}_{1} \mathrm{TD}_{50}$ and $\mathrm{TD}_{80}$ respectively.

Feeding of the Experimental Animals: Twenty female, non pregnant albino rats were randomly selected, and were divided into four groups of five and each was fed on charred meat: normal feed ratio corresponding to 0 (control) 40, 60 and 80 percental feeding patterns throughout the gestation period and three weeks thereafter, except on the night preceeding the morning prior to sacrifice.
Determination of Blood Glucose and Insulin: Initial blood sample from the pregnant rats was obtained by incision of the tail tip after massaging, pressing peripherally, and blood glucose estimation was carried out using a glucometer (One Touch Basic Plus, Johnson \& Johnson Coy. USA) for each female rat in each group prior to feeding regimen. And on the day of sacrifice whole blood from cardiac puncture was obtained for determination of blood glucose level using the above method. Serum samples were obtained after keeping the heart punctured - blood to clot within one to two hours in sample bottles at room temperature and later centrifuged at $400 \mathrm{rpm}$ for ten minutes. The samples were stored in the refrigerator at $4^{0} \mathrm{C}$ for one day before insulin estimation. The insulin estimation for each rat and each of their three randomly selected offsprings was carried out using the method of insulin microplate Elisa Kit. (Diagnostic Automation Inc., 2003).

Statistics: The student's t-test was used for comparism and analysis. Values are expressed as mean \pm SEM. Statistical significance was accepted at $\mathrm{P}<0.05$.

\section{Results}

The effect of charred meat intake on the body weight of mice is summarized on table 1 . There was significant reduction in body weight in mice that received 60,80 and 100 percent charred meat respectively compared with the control $(\mathrm{P}<0.05)$. The initial and final blood glucose level of the pregnant rats fed on 40, 60 and 80 percent dosage regimen showed no significant change $(\mathrm{P}<0.05)$ compared with the control (Table 2), whereas, there were significant dose-related changes in blood glucose level of the litters corresponding to pregnant rats fed on 60 and 80 percent dose regimen.

The serum insulin level of the pregnant rats fed on 40, 60 and 80 percent dosage regimen show no significant change compared with the control $(\mathrm{P}<0.05)$, (Table 3$)$, whereas, there were, dose related significant changes in serum insulin level of the litters of the pregnant rats that received 40 percent $(\mathrm{P}<0.05), 60$ and 80 percent $(\mathrm{P}<0.01)$ dosage regimen.

The relationship between blood glucose level and the corresponding serum insulin level of the litters of the pregnant rats that were fed on 40, 60 and 80 percent of charred meat respectively compared with the control is shown in figure 1 . The blood glucose level was significantly high whereas the serum insulin level was low compared with the control. 
Diabetogenic property of charred meat

Table 1: The effect of charred meat intake on the body weight of mice after three days feeding

\begin{tabular}{cccccc}
\hline Doses & $\begin{array}{c}\text { Initial Body } \\
\text { Weight }(\mathrm{gm}) \\
( \pm \text { SEM })\end{array}$ & $\begin{array}{c}\text { Weight at day } \\
\text { three }(\mathrm{gm}) \\
( \pm \text { SEM })\end{array}$ & $\begin{array}{c}\text { Change in body } \\
\text { weight }(\mathrm{gm})( \pm \\
\text { SEM })\end{array}$ & $\begin{array}{c}\text { Percentage } \\
\text { change in body } \\
\text { weight }\end{array}$ & $\begin{array}{c}\text { Log } \\
\text { Dose }\end{array}$ \\
\hline 0 & $21.9 \pm 0.29$ & $22.0 \pm 0.24$ & $0.12 \pm 0.07$ & 054 & 0 \\
10 & $19.6 \pm 1.10$ & $19.1 \pm 1.11$ & $0.06 \pm 0.07$ & 0.31 & 1.0 \\
20 & $19.8 \pm 2.29$ & $19.9 \pm 1.97$ & $0.04 \pm 0.08$ & 0.20 & 1.3 \\
40 & $22.6 \pm 0.76$ & $22.5 \pm 0.65$ & $0.10 \pm 0.38$ & 0.44 & 1.6 \\
60 & $22.2 \pm 0.64$ & $20.3 \pm 0.60$ & $1.88 \pm 0.19$ & 8.46 & 1.8 \\
80 & $22.6 \pm 1.47$ & $20.6 \pm 1.59$ & $2.0 \pm 0.43$ & 8.85 & 1.9 \\
100 & $12.1 \pm 0.76$ & $11.0 \pm 0.62$ & $1.1 \pm 0.33$ & 9.09 & 2.0 \\
\hline
\end{tabular}

Table 2: Plasma glucose level of pregnant rats and litters after charred meat feeding regimen during pregnancy and three weeks thereafter.

\begin{tabular}{cccc}
\hline Dose & $\begin{array}{c}\text { Blood glucose level of } \\
\text { pregnant rats before } \\
\text { feeding regimen }(\mathrm{mg} / \mathrm{dl})\end{array}$ & $\begin{array}{c}\text { Blood glucose level } \\
\text { of pregnant rats after } \\
\text { feeding regimen } \\
(\mathrm{mg} / \mathrm{dl})\end{array}$ & $\begin{array}{c}\text { Blood glucose } \\
\text { level of the litters } \\
(\mathrm{mg} / \mathrm{dl})\end{array}$ \\
\hline Control & $60.5 \pm 7.11$ & $58.3 \pm 5.09$ & $53.8 \pm 3.78$ \\
40 & $64.5 \pm 10.60^{\mathrm{NS}}$ & $55.5 \pm 13.44^{\mathrm{NS}}$ & $47.5 \pm 1.85^{\mathrm{NS}}$ \\
60 & $56.7 \pm 2.87^{\mathrm{NS}}$ & $48.3 \pm 1.08^{\mathrm{NS}}$ & $63.7 \pm 2.17^{*} \mathrm{~S}$ \\
80 & $59.7 \pm 6.44^{\mathrm{NS}}$ & $50.0 \pm 5.35^{\mathrm{NS}}$ & $64.1 \pm 139^{\mathrm{S}}$ \\
\hline
\end{tabular}

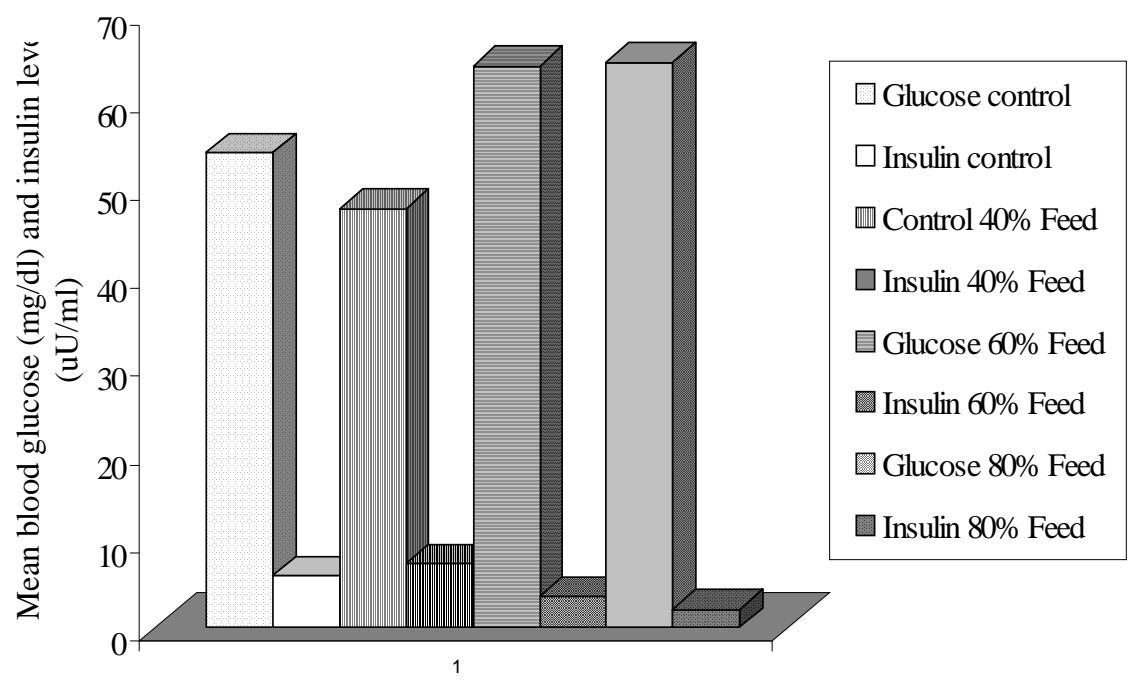

Dosage of meat in percentage mixture

Fig. 1: Shows the relationship between blood glucose and the serum insulin levels of the litters of pregnant rats fed on 40,60 and 80 percent dosage regimen of charred meat compared with the control ( $\pm S E M)$. 
Table 3: The effect of charred meat intake on serum insulin level of pregnant albino rats and litters.

\begin{tabular}{ccc}
\hline Dose & $\begin{array}{c}\text { Serum Insulin } \\
\text { level } \mu \mathrm{U} / \mathrm{ml} \\
\left(\begin{array}{c}\text { pregnant rats }) \\
(\mathrm{n}=5)\end{array}\right.\end{array}$ & $\begin{array}{c}\text { Serum Insulin } \\
\text { level } \mu \mathrm{U} / \mathrm{ml} \\
\text { litters } \\
(\mathrm{n}=5)\end{array}$ \\
\hline Control & $6.1 \pm 0.70$ & $5.8 \pm 0.29$ \\
40 & $6.0 \pm 1.41^{\mathrm{NS}}$ & $7.2 \pm 0.48 * \mathrm{~s}$ \\
60 & $7.7 \pm 2.28 \mathrm{NS}$ & $3.4 \pm 0.72 * * \mathrm{~s}$ \\
& & \\
80 & $7.6 \pm 0.31^{\mathrm{NS}}$ & $2.0 \pm 0.43 * * \mathrm{~s}$ \\
\hline$*$ & $\mathrm{P}<0.05 * * \mathrm{P}<0.01$ & \\
\end{tabular}

\section{Discussion}

The results of this study showed increased blood glucose level and reduced serum insulin level in litters of pregnant rats exposed to charred meat. In this present investigation, the results have, to a large extent, shown the role of charred meat in the development of type 1 diabetes mellitus. It has also shown that the diabetogenic effect did not depend on curing of meat with nitrates or nitrites containing food additives only, (Helgason et al 1982) rather, and likely, the naturally occuring nitrosamine in meat, when subjected to charcoal fire roasting could be raised to a concentration level toxic enough to cause type 1 diabetes mellitus in the litters of pregnant albino rats fed on this meat during gestation and lactation periods.

Meat for this study was not cured since nitrates and nitrites used in curing could be influenced by bacterial action in Gastrointestinal Tract and heat to form series of different N-Nitroso compounds (nitrosamines and nitrosamides) (Rywotycki, 2000) for example, streptozotocin, which is a proven diabetogenic agent. No consideration was given to the intensity of charcoal fire or the uniformity in the distribution of heat. The aim was to simulate condition almost identical to that obtained locally. Refrigeration of the meat was avoided in order to prevent posible decomposition of some food compounds in the meat. It is worth noting that Dimethylnitrosamine and Diethyllnitrosamine present in meat, when subjected to heat can act synergistically with other mutagenic agents, such as polycyclic aromatic hydrocarbons, heterocyclic amines (Veith, 2004 and Sugimara, 1985) and these have been found in very traceable amount in meat especially when subjected to smoking. The results could not show evidence of diabetes mellitus in the pregnant rats that consumed the charred meat; rather, the litters had significant incidence of diabetic indicies of hyperglycaemia and hypoinsulinaemia.

In 1965, Okamoto showed that diabetes induced in rats, rabbits and guinea pigs by alloxan, with subsequent inbreeding of the diabetic animals, induced spontaneous diabetes in generations up to fifth, and seventh (Helgason, et al 1982). The authors attributed the observations to the hyperglycaemia of the parents. These diabetic conditions were prevented in the subsequent generations by correcting the hyperglycaemia in the parents four days prior to fertilization. The results of this study, however differ from such observation in that the pregnant rats never developed an overt diabetes.

There were significant indicators or parameters of diabetes among litters of rats compared to those reported in progeny of mice by Helgason et al (1982). Single point glucose tolerance tests were done after 18 hours overnight fasts and the mice were considered diabetic if plasma glucose level was equal to or exceeded $211 \mathrm{mg} / \mathrm{dl}$. and the plasma glucose level ranged from $211-269 \mathrm{mg} / \mathrm{dl}$. The corresponding serum insulin level was $9-20$ $\mu \mathrm{U} / \mathrm{ml}$ compared with $25-45 \mu \mathrm{U} / \mathrm{ml}$ in the control groups. This study did not consider glucose tolerance test very appropriate since low serum insulin level and the corresponding high blood glucose level were significant parameters to confirm diabetics in the litters. They were considered diabetic if the blood glucose level was equal to or higher than $63.7 \pm$ $2.17 \mathrm{mg} / \mathrm{dl}$ compared with the control of $53.8 \pm$ $3.78 \mathrm{mg} / \mathrm{dl} 2$ tailed test at $\mathrm{P}<0.05$. Thus, the mean blood glucose level of the litters that were diabetic was $63.7 \pm 2.17$ and $64.1 \pm 1.39 \mathrm{mg} / \mathrm{dl}$ and the corresponding serum insulin level was $3.4 \pm 0.72 \mu \mathrm{U} / \mathrm{ml}$ and $2.0 \pm 0.43 \mu \mathrm{U} / \mathrm{ml}$, respectively. Therefore, the diabetic condition of the animals in this present study was severer than previously reported by Helgason et al (1982). The mean serum insulin value was low 
$(2.0 \mu \mathrm{U} / \mathrm{ml})$ compared with $9.0 \mu \mathrm{U} / \mathrm{ml}$ reported by Helgason et al (1982) in their study on mice. The view expressed by Craighead (1978) on the aetiology of type 1 diabetes indicated HLA susceptibility, islet cell antibodies, and the genetic effects of viruses and chemicals. It is probably that nitrosamine in meat, a $\mathrm{N}$-nitroso compound, may well fit the role of a chemical mutagen in this study. The findings from this study suggest and confirm the environmental factor (in this case, the nitrosamine containd in the meat) in the aetiology of type 1 diabetes mellitus. This contributory environmental factor is dose-related and the mechanism seems to involve maternal influences on germ cells, and could also be transfer through lactation or placenta.

\section{References}

Craighead J. E. (1978). Current Views on the Etiology of InsulinDependent Diabetes. British Journal of Med. 299. 1439-1445.

Dahlquist G., Bloom L. and Lonnberg G. (1991). The Swedish Childhood Diabetes Study. Diabetologia 34. 757-762.

Felton, J. S. and Knize M. G. (1990). Heterocyclic-amine

Mutagens/Carcinogens in Foods. Handbook of Experimental Pharmacology 94/1. Berlin. $471-480$.

Helgason T., Ewen S. W. B., Ross L. S. and Stowers J. M. (1982). Diabetes Produced in Mice by Smoked/cured Mutton. The Lancet November 1017 - 1021.

Nwafor A. and Owhoji A. (2001). Prevalence of Diabetes Mellitus among Nigerians in Port Harcourt Correlates with Socioeconomic Status. JASEM ISSN- 1119. 7577.

Okamoto K. (1965) Apparent transmittance of factors to offspring by animals with experimental diabetes. Excerpta medica, Amsterdam, 627-640.
Ruwaard D, Hirasing R. A., Reeser H. M., Van Buurens Bakker K., Heine R. J., Geerdink R. A., Bruining G. J., Vaandrager G. J. and Verloove - Vanlorick S. P. (1994) Increasing incidence of type 1 diabetes in the Netherlands. Diabetes Care 17:599601.

Rywotycki, R. (2000). Influence of Technological Processes and Functional Additives on the Nitrosamine Level in Meat. Linus Pauling Institute. R/Krakowa. Poland, 267-272.

Sugimura T. (1985). Carcinogenicity of Mutagenic Hetero-cyclic Amines Formed During Cooking Process. Mutation Research. 150, 33-41

Takayuki S. and Bjeldanes L. (1993). Introduction to food Toxicology. Academic Press, San Diego. 191-196.

Van Maanen JMS, Welle I.J., Hageman G, Darllinga J. W., Mertins PLJ.M. and Klejans JCS (1996). Nitrate Contamination of Drinking Water: Relationship with Lymphocyte DNA and Urinary Excretion of Nitrosamine. Environs Health Perspective 104: 522299.

Van Maanen, JMS, Harma J. and Simone E. (2000). Does the Risk of Childhood Diabetes Mellitus Require Revision of the Guideline for Nitrate in Drinking Water? jvanmaannen@grat.unimaas.ne.

Veith, W. J. (2004). Dietary Hazards (Meat) Health Articles. Page Updated Publication.

Verge S. M., Howard N. J. and Silink M. (1994). Environmental factors in childhood IDDM. A Population-based Case Control Study. Diabetes Care. 17, $1381-1386$.

Received: 26/7/06

Accepted: 24/11/06 